\title{
Biorational management of maize fall armyworm, Spodoptera frugiperda (J. E. Smith) (Lepidoptera: Noctuidae) using Bacillus thuringiensis (Berliner) enriched with chemical additives
}

\section{Priyanka*}

Department of Plant Protection, Anbil Dharmalingam Agricultural College and Research Institute, Tamil Nadu Agriculture University, Tiruchirapalli - 620027 (Tamil Nadu), India

\section{P.Yasodha}

Department of Plant Protection, Anbil Dharmalingam Agricultural College and Research Institute, Tamil Nadu Agriculture University, Tiruchirapalli - 620027 (Tamil Nadu), India

C.Gailce Leo Justin

Department of Plant Protection, Anbil Dharmalingam Agricultural College and Research Institute, Tamil Nadu Agriculture University, Tiruchirapalli - 620027 (Tamil Nadu), India

\section{J. Ejilane}

Department of Soil Science and Agricultural Chemistry, Anbil Dharmalingam Agricultural College and Research Institute, Tamil Nadu Agriculture University, Tiruchirapalli - 620027 (Tamil Nadu), India

\section{Venugopal Rajanbabu}

Department of Plant Breeding and Genetics, Anbil Dharmalingam Agricultural College and Research Institute, Tamil Nadu Agriculture University, Tiruchirapalli - 620027 (Tamil Nadu), India

*Corresponding author. Email: priyankamuguntharaja@gmail.com

\section{How to Cite}

Priyanka, M. et al. (2021). Biorational management of maize fall armyworm, Spodoptera frugiperda (J. E. Smith) (Lepidoptera: Noctuidae) using Bacillus thuringiensis (Berliner) enriched with chemical additives. Journal of Applied and Natural Science, 13 (4), 1231 - 1237. https://doi.org/10.31018/jans.v13i4.2999

\begin{abstract}
An invasive pest, fall armyworm, Spodoptera frugiperda (J.E.Smith) (Lepidoptera: Noctuidae) attacks maize at every stage of development, from seedling emergence up to cob formation. Early instar larvae were seen mostly on leaves of maize with characteristics pin or shot hole symptoms. Later instar larvae were confined to deep whorls, leaving typically ragged like appearance and fed on the reproductive stage of the crop especially tassels and developing cobs resulting in quality and quantity loss of maize produce. The effect of commercially available Bacillus thuringiensis subsp. kurstaki product, Dipel ${ }^{\circledR}$ against the second instar larvae of Fall Armyworm (FAW )was not promising under laboratory conditions. Hence, an effort was made to add an adjuvant along with $B$. thuringiensis to increase the virulence of commercially available $B$. thuringiensis. The Laboratory bioassays with $B$. thuringiensis and seven chemical additives ( T1- Bt + Boric acid, T2- Bt + Zinc oxide, T3- Bt + Sodium nitrate, T4$B t+$ Peptone, T5- Bt + Urea, T6- Bt + EDTA, T7- Bt + Citric acid \& T8- Bt alone T9- Control) were tested against second instar larvae of Spodoptera frugiperda larvae. The results showed that $B$. thuringiensis plus sodium nitrate (T3) promoted maximum mortality 82.2 per cent with a minimum $\mathrm{LC}_{50}$ value of $54.620 \mathrm{mg} / \mathrm{l}$. Sodium nitrate boosted $B$. thuringiensis activity at a concentration of 0.05 per cent by 2.128 -fold than $B$. thuringiensis alone. Overall, sodium nitrate improved the efficacy of $B$. thuringiensis spray at the maximum level followed by boric acid, urea, EDTA and peptone.
\end{abstract}

Keywords: Spodoptera frugiperda, B. thuringiensis, Chemical additives, Synergistic interaction

\section{INTRODUCTION}

The fall armyworm (FAW), Spodoptera frugiperda (J. E. Smith, 1797) (Lepidoptera: Noctuidae) is an exotic, polyphagous insect pest that originated in the Americas
(Luginbill, 1928). Almost 100 plant species are affected by Fall Armyworm (FAW), including maize, sorghum, rice, soybean, cotton, wheat and sugarcane. In addition, Montezano et al. (2018) reported 353 hosts from 76 plant families with the Gramineae family having the 
largest hosts with106 taxa, followed by Asteraceae and Fabaceae with 31 taxa each. Despite its ability to live in various host plants, the FAW is known to predominantly infest Maize (Nagoshi et al., 2018). FAW was first recorded in West and Central Africa in 2016. Eventually, it also spreads to other continents of the world, wreaking havoc on maize production (Goergen et al., 2016). Bacillus thuringiensis (Berliner) is a gram-positive, sporeforming bacteria is a most promising biopesticide used against lepidopteran pests (Baum et al., 1999). Though it is used in commercial agriculture, forest pest management and mosquito control as an alternative to chemical pesticides, it has some drawbacks which limit its application, such as its limited scope of action and short duration in the field (Opisa et al., 2020). As a result, several strategies to improve the potency of $B$. thuringiensis toxin are now being researched. Feeding stimulants, pesticides, allelochemicals, chemicals, other microbial pesticides, proteins such as serine protease inhibitors, chitinases, Cyt toxins, or cadherin fragments were used as additives to improve the efficacy of $B$. thuringiensis (Marzban et al., 2009).

In this context, an effort was undertaken to enhance the toxic effect of $B$. thuringiensis by the addition of chemical substitutes. The chemical additives were integrated with the commercial formulation of $B$. thuringiensis sub sp. Kurstaki $\left(\right.$ Dipel $\left.^{\circledR}\right)$ and test were verified against second instar larvae of FAW that could considerably improve $B$. thuringiensis efficacy by broadening the range of the activity of $B$. thuringiensis formulation.

\section{MATERIALS AND METHODS}

\section{Insect culture}

The FAW culture was maintained using International Maize and Wheat Improvement Centre (CIMMYT) diet (Songa et al.,2004) at a temperature of $27 \pm 7^{\circ} \mathrm{C}$ and 70 per cent relative humidity at PG Entomology Laboratory of the Department of Plant Protection, Anbil Dharmalingam Agricultural College and Research Institute, Tiruchirappalli.

The first and second instar of FAW was reared using maize leaves. FAW egg masses were placed in round plastic containers ( $24.5 \mathrm{~cm}$ dia. $\times 19.5 \mathrm{~cm} \mathrm{ht}$.) with filter paper at the bottom. Muslin cloth was used to cover the mouth of the round plastic containers. After hatching, the neonates were fed with tender maize leaves. The second instar larvae were reared individually on a small individual plastic container ( $5 \mathrm{~cm}$ dia. $\times 5 \mathrm{~cm} \mathrm{ht}$.) to prevent cannibalism of FAW and covered with gadda cloth. The pupae were collected and transferred to the rearing cages $(30 \mathrm{~cm} \mathrm{I} \times 30 \mathrm{~cm} \mathrm{~b} \times 45 \mathrm{~cm} \mathrm{ht}$.) as and when pupated. Glass vials containing sterile absorbent cotton with 10 per cent adult diet served as adult food (Ashok et al., 2020). The maize seedlings maintained in plastic trays $(15 \mathrm{~cm} \mathrm{I} \times 7.5 \mathrm{~cm} \mathrm{~b})$ served as oviposition substrate inside the oviposition cages $(30 \mathrm{~cm} \mathrm{I} \mathrm{x} 30 \mathrm{~cm} \mathrm{~b} \times$ $45 \mathrm{~cm} \mathrm{ht.).} \mathrm{The} \mathrm{newly} \mathrm{emerged} \mathrm{adults} \mathrm{were} \mathrm{confined}$ for oviposition on maize and the rearing continued as mentioned earlier.

\section{Chemical additives}

Chemical additives were tested to improve the efficacy of the B. thuringiensis subsp. kurstaki product Dipel ${ }^{\circledR}$ against second instar larvae of FAW. The seven chemical additives employed in this investigation were inorganic salts (boric acid and zinc oxide), nitrogenous chemicals (peptone, sodium nitrate), protein solubilizing agents (urea and ethylene diamine tetra acetate [EDTA]) and organic acids (citric acid). The safe and low-cost additives from SigmaAldrich ${ }^{\circledR}$ Chemical Company, USA were selected for the study to improve the virulence of $B$. thuringiensis. Dipe ${ }^{\circledR} 8 \mathrm{~L}$, a commercial formulation of $B$. thuringiensis var kurstaki strain HB-1, serotype $\mathrm{H} 3 \mathrm{a}, 3 \mathrm{~b}$ formulated as a $3.5 \%$ Emulsifiable Suspension (ES) with $17,600 \mathrm{IU} / \mathrm{mg}$ potency, obtained from Valent BioSciences, USA was utilized for the study.

\section{Effects of additives on second instar larvae of FAW}

Before testing with $B$. thuringiensis product, additives were tested individually against second instar larvae of FAW using leaf disc method. Two fresh young maize leaves collected from 2 to 3 -week old seedlings of identical size (90 $\mathrm{mm}$ in dia.) were used for the bioassay. The fresh leaves were treated with ten $\mathrm{ml}$ of 0.05 per cent additive containing few drops of 0.05 per cent Triton $X 100$. After treatment, the leaves were air-dried for around $5 \mathrm{~min}$. in a sterile laminar airflow chamber to eliminate any excess moisture. To maintain turgidity, the leaves were then placed over a moistened filter paper $(110 \times 60 \mathrm{~mm})$ in a transparent 6 well tissue culture plates (HiMedia Laboratories Pvt. Ltd, Telangana). Eight treatments viz., T1 (Boric acid), T2 (Zinc oxide), T3 (Sodium nitrate), T4 (Peptone), T5 (Urea), T6 (EDTA), T7 (Citric acid), T8 (Control) and three replications were maintained. Each replication contained 15 second instar larvae. The control plate was sprayed with sterilized distilled water. During the first $24 \mathrm{~h}$, the larvae were fed with additive treated leaves and after that, fresh maize leaves was replenished as and when after cleaning. The larval mortality was recorded for a week at $24 \mathrm{~h}$ intervals. The experiment was carried out using a completely randomized design.

\section{Bioassay with B. thuringiensis and chemical additives}

The bioassay was carried out as described above with $B$. thuringiensis and additives, fresh leaves were treated with a mixture of $5 \mathrm{ml}$ of 0.05 per cent of additive and $5 \mathrm{ml}$ of 0.2 per cent Dipe ${ }^{\circledR}(B$. thuringiensis subsp. 
kurstaki). Nine treatments viz., T1 $(0.2 \% B t+0.05 \%$ Boric acid), T2 $(0.2 \% B t+0.05 \%$ Zinc oxide), T3 $(0.2 \%$ $B t+0.05 \%$ Sodium nitrate), T4 $(0.2 \% B t+0.05 \%$ Peptone), T5 $(0.2 \% B t+0.05 \%$ Urea $)$, T6 $(0.2 \% B t+$ $0.05 \%$ EDTA $),$ T7 $(0.2 \% B t+0.05 \%$ Citric acid $)$, T8 $(0.2 \%$ Bt alone), T9 (Control) and three replications were maintained. Each replication contained 15 second instar larvae and the control plate was sprayed with sterilized distilled water. The chemical additives in combination with $B$. thuringiensis which produced less than 50 per cent larval mortality were not selected for probit analysis.

\section{Statistical analysis}

Mortality data obtained were converted to arc-sine values and subjected to Completely Randomised Design using Agres-agdata package. To correct the mortality in control, Abbott's formula was utilised and median lethal doses $\left(L_{50}\right)$ were calculated using probit analysis (Finney, 1971).

\section{RESULTS AND DISCUSSION}

Effects of additives on second instar larvae of FAW The mortality caused by additives alone against second instar FAW larvae ranged from 08.88 per cent to 33.33 per cent, with sodium nitrate causing the highest mortality $(33.33 \%)$ while zinc oxide caused the lowest mortality $(08.88 \%)$ on 168 Hours After Treatment (HAT).
Efficacy of $B$. thuringiensis in combination with additives against second instar larvae of FAW When each additive tested together with $B$. thuringiensis resulted in higher mortality than when they were used alone. The mortality caused by the combination of $B$. thuringiensis with additives against second instar larvae of FAW ranged from 82.22 per cent to 28.88 per cent, with sodium nitrate caused the highest mortality $(82.22 \%)$ while zinc oxide produced the lowest mortality $(13.33 \%)$ on 168 HAT (Table 1). The weight reduction of surviving larvae over control in 168 HAT was maximum in $B$. thuringiensis plus sodium nitrate $(59.84 \%)$ followed by $B$. thuringiensis plus boric acid $(59.55 \%)$, B. thuringiensis plus urea $(57.68 \%), B$. thuringiensis plus EDTA (54.38\%), B. thuringiensis plus peptone $(51.40 \%)$, B. thuringiensis plus citric acid (48.19\%) and $B$. thuringiensis plus zinc oxide $(41.98 \%)$ (Table 3)

\section{Effects of $B$. thuringiensis and inorganic salts}

The $B$. thuringiensis plus inorganic salts and the $B$. thuringiensis alone produced a significant difference in larval mortality. The $B$. thuringiensis plus boric acid mixture caused higher mortality, with the $L_{50}$ being $62.459 \mathrm{mg} / \mathrm{l}$, compared to $116.239 \mathrm{mg} / \mathrm{l}$ for B. thuringiensis alone. The 26.67 percent survived larvae showed 59.55 per cent larval weight reduction in comparison over control (Table 3). Boric acid had shown to enhance the effectiveness of $B$. thuringiensis against

Table 1. Effects of additives against second instar larvae of FAW

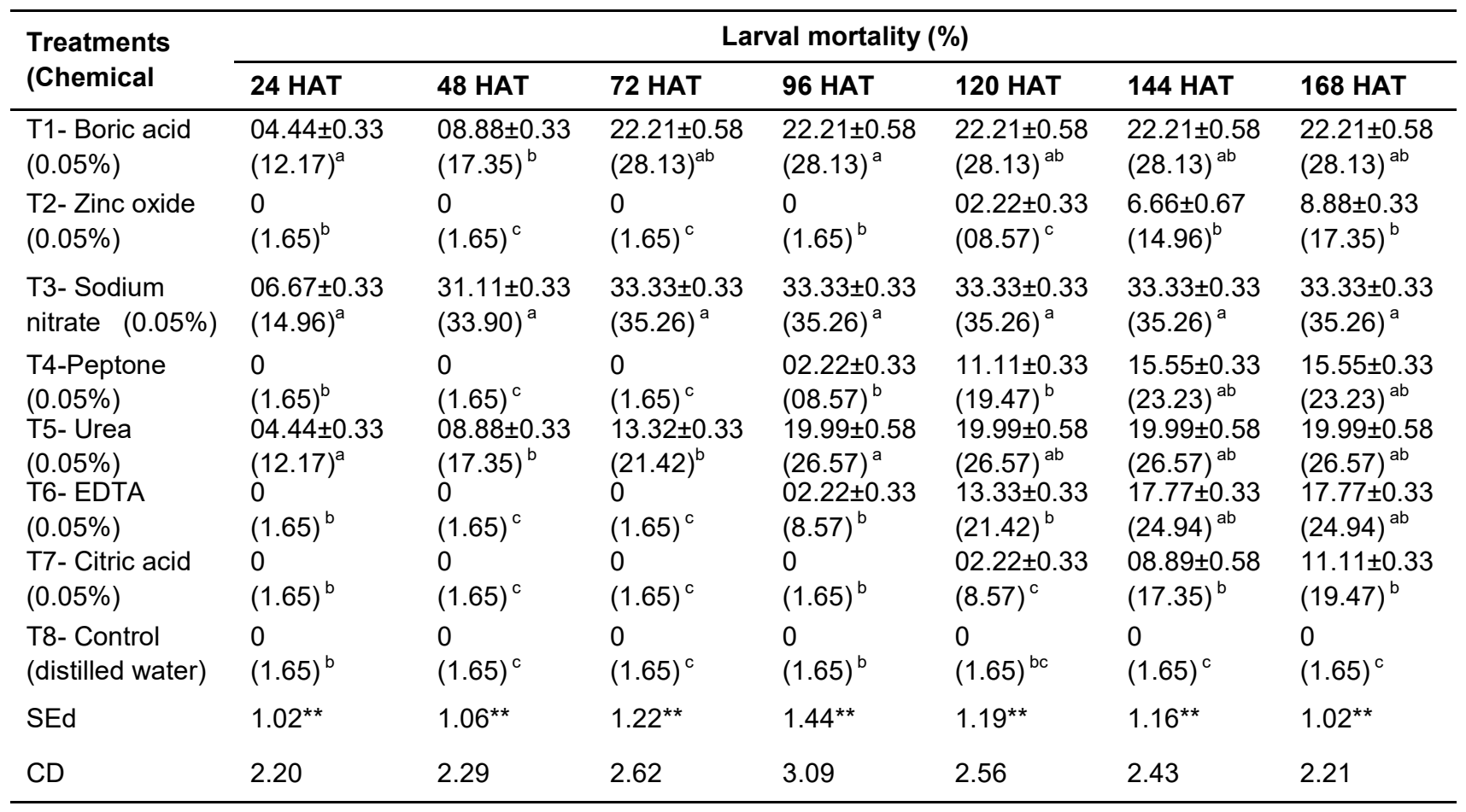

Note *Each value is a mean of three replications (Mean $\pm S E$ ); *Figures within parentheses are arcsine transformed values; *Means followed by common alphabets are not significantly different at $5 \%$ level by LSD; *HAT- Hours after treatment 
Priyanka, M. et al. / J. Appl. \& Nat. Sci. 13(4), 1231 - 1237 (2021)

\begin{tabular}{|c|c|c|c|c|c|c|c|}
\hline \multirow{2}{*}{$\begin{array}{l}\text { Treatments } \\
\text { with } B t+ \\
\text { Chemical } \\
\text { additives }\end{array}$} & \multicolumn{7}{|c|}{ Larval mortality (\%) } \\
\hline & 24 HAT & 48 HAT & 72 HAT & 96 HAT & $120 \mathrm{HAT}$ & 144 HAT & 168 HAT \\
\hline $\begin{array}{l}\text { T1- Bt }(0.2 \%)+ \\
\text { Boric acid } \\
(0.05 \%)\end{array}$ & $\begin{array}{l}08.89 \pm 0.88 \\
(17.35)^{\mathrm{b}}\end{array}$ & $\begin{array}{l}26.67 \pm 0.66 \\
(31.09)^{\mathrm{b}}\end{array}$ & $\begin{array}{l}57.78 \pm 0.88 \\
(49.47)^{\mathrm{b}}\end{array}$ & $\begin{array}{l}68.89 \pm 0.33 \\
(56.10)^{\mathrm{ab}}\end{array}$ & $\begin{array}{l}73.33 \pm 0.33 \\
(58.90)^{a}\end{array}$ & $\begin{array}{l}73.33 \pm 0.33 \\
(58.90)^{\mathrm{ab}}\end{array}$ & $\begin{array}{l}73.33 \pm 0.33 \\
(58.90)^{a}\end{array}$ \\
\hline $\begin{array}{l}\text { T2- Bt }(0.2 \%)+ \\
\text { Zinc oxide } \\
(0.05 \%)\end{array}$ & $\begin{array}{l}0 \\
(1.65)^{\mathrm{c}}\end{array}$ & $\begin{array}{l}0 \\
(1.65)^{d}\end{array}$ & $\begin{array}{l}02.22 \pm 0.33 \\
(8.57)^{\mathrm{fg}}\end{array}$ & $\begin{array}{l}06.66 \pm 0.33 \\
(14.96)^{\mathrm{e}}\end{array}$ & $\begin{array}{l}11.10 \pm 0.33 \\
(19.47)^{f}\end{array}$ & $\begin{array}{l}22.21 \pm 0.33 \\
(28.12)^{\mathrm{e}}\end{array}$ & $\begin{array}{l}28.88 \pm 0.33 \\
(32.51)^{d}\end{array}$ \\
\hline $\begin{array}{l}\text { T3- } B t(0.2 \%)+ \\
\text { Sodium nitrate } \\
(0.05 \%)\end{array}$ & $\begin{array}{l}24.44 \pm 0.33 \\
(29.63)^{a}\end{array}$ & $\begin{array}{l}64.44 \pm 0.58 \\
(53.40)^{a}\end{array}$ & $\begin{array}{l}82.22 \pm 0.33 \\
(65.06)^{a}\end{array}$ & $\begin{array}{l}82.22 \pm 0.33 \\
(65.06)^{a}\end{array}$ & $\begin{array}{l}82.22 \pm 0.33 \\
(65.06)^{a}\end{array}$ & $\begin{array}{l}82.22 \pm 0.33 \\
(65.06)^{a}\end{array}$ & $\begin{array}{l}82.22 \pm 0.33 \\
(65.06)^{a}\end{array}$ \\
\hline $\begin{array}{l}\text { T4- Bt }(0.2 \%)+ \\
\text { Peptone } \\
(0.05 \%)\end{array}$ & $\begin{array}{l}0 \\
(1.65)^{c}\end{array}$ & $\begin{array}{l}04.44 \pm 0.33 \\
(12.17)^{\mathrm{cd}}\end{array}$ & $\begin{array}{l}08.88 \pm 0.33 \\
(17.35)^{\mathrm{de}}\end{array}$ & $\begin{array}{l}19.99 \pm 0.33 \\
(26.57)^{\mathrm{cd}}\end{array}$ & $\begin{array}{l}39.99 \pm 0.58 \\
(39.23)^{\mathrm{cd}}\end{array}$ & $\begin{array}{l}53.32 \pm 0.58 \\
(46.91)^{\mathrm{bc}}\end{array}$ & $\begin{array}{l}62.21 \pm 0.33 \\
(52.07)^{a b}\end{array}$ \\
\hline $\begin{array}{l}\text { T5- Bt(0.2\%)+ } \\
\text { Urea } \\
(0.05 \%)\end{array}$ & $\begin{array}{l}06.67 \pm 0.33 \\
(14.96)^{b}\end{array}$ & $\begin{array}{l}22.23 \pm 0.33 \\
(28.13)^{\mathrm{b}}\end{array}$ & $\begin{array}{l}33.34 \pm 0.33 \\
(35.26)^{c}\end{array}$ & $\begin{array}{l}57.78 \pm 0.33 \\
(49.47)^{\mathrm{b}}\end{array}$ & $\begin{array}{l}64.45 \pm 0.33 \\
(53.40)^{a b}\end{array}$ & $\begin{array}{l}71.12 \pm 0.33 \\
(57.49)^{a b}\end{array}$ & $\begin{array}{l}71.12 \pm 0.33 \\
(57.49)^{a}\end{array}$ \\
\hline $\begin{array}{l}\text { T6- Bt }(0.2 \%)+ \\
\text { EDTA } \\
(0.05 \%)\end{array}$ & $\begin{array}{l}0 \\
(1.65)^{\mathrm{c}}\end{array}$ & $\begin{array}{l}08.89 \pm 0.33 \\
(17.35)^{c}\end{array}$ & $\begin{array}{l}15.56 \pm 0.33 \\
(23.23)^{d}\end{array}$ & $\begin{array}{l}26.67 \pm 0.33 \\
(31.09)^{\mathrm{c}}\end{array}$ & $\begin{array}{l}48.89 \pm 0.33 \\
(44.36)^{\mathrm{bc}}\end{array}$ & $\begin{array}{l}64.45 \pm 0.33 \\
(53.40)^{a b}\end{array}$ & $\begin{array}{l}68.89 \pm 0.33 \\
(56.10)^{a b}\end{array}$ \\
\hline $\begin{array}{l}\text { T7- Bt }(0.2 \%)+ \\
\text { Citric acid } \\
(0.05 \%)\end{array}$ & $\begin{array}{l}0 \\
(1.65)^{\mathrm{c}}\end{array}$ & $\begin{array}{l}02.22 \pm 0.33 \\
(08.57)^{\mathrm{d}}\end{array}$ & $\begin{array}{l}06.66 \pm 0.33 \\
(14.96)^{\text {def }}\end{array}$ & $\begin{array}{l}13.33 \pm 0.33 \\
(21.42)^{\text {de }}\end{array}$ & $\begin{array}{l}22.22 \pm 0.33 \\
(28.13)^{\mathrm{e}}\end{array}$ & $\begin{array}{l}28.89 \pm 0.58 \\
(32.51)^{\mathrm{de}}\end{array}$ & $\begin{array}{l}35.56 \pm 0.33 \\
(36.60)^{\text {cd }}\end{array}$ \\
\hline $\begin{array}{l}\text { T8- Bt alone } \\
(0.2 \%) \\
\text { T9- Control } \\
\text { (distilled water) }\end{array}$ & $\begin{array}{l}0 \\
(1.65)^{\mathrm{c}} \\
0 \\
(1.65)^{\mathrm{C}}\end{array}$ & $\begin{array}{l}0 \\
(1.65)^{d} \\
0 \\
(1.65)^{d}\end{array}$ & $\begin{array}{l}04.44 \pm 0.33 \\
(12.17)^{\text {efg }} \\
0 \\
(1.65)^{\mathrm{fg}}\end{array}$ & $\begin{array}{l}11.11 \pm 0.33 \\
(19.47)^{\mathrm{de}} \\
0 \\
(1.65)^{\mathrm{f}}\end{array}$ & $\begin{array}{l}24.41 \pm 0.33 \\
(29.63)^{\mathrm{de}} \\
0 \\
(1.65)^{\mathrm{g}}\end{array}$ & $\begin{array}{l}39.97 \pm 0.33 \\
(39.23)^{\text {cd }} \\
0 \\
(1.65)^{f}\end{array}$ & $\begin{array}{l}48.86 \pm 0.33 \\
(44.36)^{\mathrm{bc}} \\
0 \\
(1.65)^{\mathrm{e}}\end{array}$ \\
\hline SEd & $1.16^{\star *}$ & $1.49^{* *}$ & $1.57^{\star *}$ & $1.42^{* *}$ & $1.63^{* *}$ & $1.65^{\star *}$ & $1.56^{* *}$ \\
\hline$C D$ & 2.43 & 3.14 & 3.29 & 3.00 & 3.43 & 3.46 & 3.27 \\
\hline
\end{tabular}

Note *Each value is a mean of three replications (Mean \pm SE); *Figures within parentheses are arcsine transformed values; *Means followed by common alphabets are not significantly different at $5 \%$ level by LSD; *HAT- Hours after treatment

tobacco cutworm Spodoptera litura (Govindarajan et al.,1976), which was consistent with our results. Boric acid is a stomach and contact poison. It damages the protective layer of the peritrophic membrane and gut lining, allowing $B$. thuringiensis toxin to reach the insect midgut epithelium and therefore increasing the effectiveness of toxicity (Govindarajan et al.,1976).

$B$. thuringiensis plus zinc oxide combination caused mortality of 28.88 per cent on the 168 HAT, which was much lower than the mortality produced by boric acid containing mixture with $B$. thuringiensis $(73.3 \%)$ and more than 70 per cent survivors showed 41.98 per cent larval weight reduction. The zinc oxide proved ineffective at increasing the potential of $B$. thuringiensis and caused lower mortality than when $B$. thuringiensis was used alone. The failure of $B$. thuringiensis to potentiate against second instar of FAW larvae could be attributed to variances in the $B$. thuringiensis strain employed in this investigation and the heterogeneous nature lepidopteran insect species and their associated gut flora or microbiome. In contrast, Malaikozhundan et al. (2017) found that $B$. thuringiensis $\mathrm{ZnO}$ nanoparticles were particularly effective against $C$. maculatus, causing $100 \%$ mortality at a $25 \mathrm{~g} / \mathrm{ml}$ concentration, which ultimately reduced the activity of midgutamylase, cysteine protease, glucosidase and glutathione Stransferase (GST).

\section{Effects of $B$. thuringiensis and nitrogenous compounds}

The sodium nitrate $(0.05 \%)$ and peptone $(0.05 \%)$, when applied in combination with $B$. thuringiensis $(0.2 \%)$, produced the larval mortality of 82.22 per cent and 62.21 per cent on 168 HAT, respectively. B. thuringiensis plus sodium nitrate recorded maximum mortality $(82.22 \%)$ among all additives with $\mathrm{LC}_{50}$ values of $54.620 \mathrm{mg} / \mathrm{l}$ and synergistically improved the activity of $B$. thuringiensis by 2.128 -fold. The remaining 17.78 per cent of survivors showed 59.84 per cent larval weight inhibition in comparison over control. Sodium nitrate was the most efficient nitrogenous substance in suppressing the second instar of FAW larvae with $B$. thuringiensis, followed by peptone. This is similar to the results of Zhang et al.(2013), who reported that nitroge- 
Priyanka, M. et al. / J. Appl. \& Nat. Sci. 13(4), 1231 - 1237 (2021)

Table 3. Effects of Bacillus thuringiensis plus additives on sub-lethal effects on second instar larvae of FAW

\begin{tabular}{llllll}
\hline $\begin{array}{l}\text { Treatments with Bt + Chem- } \\
\text { ical additives }\end{array}$ & \multicolumn{2}{l}{\begin{tabular}{l} 
Survival population \\
\cline { 2 - 5 }
\end{tabular}} & no. & Larval Weight $(\mathbf{m g}) \mathbf{1 6 8} \mathbf{h}$ & $\begin{array}{l}\text { Larval weight inhibi- } \\
\text { tion in comparison } \\
\text { over control (\%) }\end{array}$ \\
\hline T1 - Bt + Boric acid & 12 & 26.67 & $20-30$ & $27.08 \pm 2.75$ & 59.55 \\
T2 - Bt + Zinc oxide & 32 & 71.12 & $34-44$ & $38.84 \pm 2.10$ & 41.98 \\
T3 - Bt + Sodium nitrate & 08 & 17.78 & $23-29$ & $26.88 \pm 1.73$ & 59.84 \\
T4 - Bt + Peptone & 17 & 37.79 & $30-36$ & $32.53 \pm 1.55$ & 51.40 \\
T5 - Bt + Urea & 12 & 28.88 & $27-29$ & $28.33 \pm 0.89$ & 57.68 \\
T6 - Bt + EDTA & 13 & 31.11 & $30-32$ & $30.54 \pm 0.78$ & 54.38 \\
T7 - Bt + Citric acid & 28 & 64.44 & $32-37$ & $34.68 \pm 1.06$ & 48.19 \\
T8 - Bt alone & 23 & 51.14 & $32-42$ & $37.96 \pm 1.99$ & 43.29 \\
T9 - Control (distilled water) & - & - & $55-74$ & $66.94 \pm 6.02$ & - \\
\hline
\end{tabular}

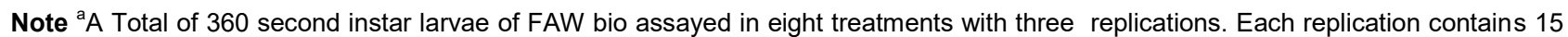
larvae $\left(15^{\star} 8^{*} 3\right)$. Survivors from each treatmentwas collected and larval weight was recorded individually.

Table 4. Dosage - mortality response of Bacillus thuringiensis plus additives on second instar larvae of FAW

\begin{tabular}{|c|c|c|c|c|c|c|c|}
\hline \multirow{2}{*}{$\begin{array}{l}\text { Treatments with } B t+ \\
\text { Chemical additives }\end{array}$} & \multirow{2}{*}{$\begin{array}{l}\mathrm{LC}_{50} \\
(\mathrm{mg} / \mathrm{l})\end{array}$} & \multirow{2}{*}{$\begin{array}{l}\text { Fold } \\
\text { increase }\end{array}$} & \multicolumn{2}{|c|}{ Fiducial Limit (95\%) } & \multirow{2}{*}{$Y=b x+a$} & \multirow[t]{2}{*}{$\mathbf{R}^{2}$} & \multirow{2}{*}{$x^{2}$} \\
\hline & & & Lower limit & Upper limit & & & \\
\hline T8 - Bt alone & 116.239 & - & 21.899 & 616.978 & $Y=0.496 x+3.977$ & 0.875 & 0.985 \\
\hline $\mathrm{T} 3-B t+$ Sodium nitrate & 54.620 & 2.128 & 16.565 & 180.106 & $Y=0.815 x+3.574$ & 0.910 & 0.999 \\
\hline $\mathrm{T} 1-B t+$ Boric acid & 62.459 & 1.861 & 14.728 & 264.871 & $Y=0.605 x+3.883$ & 0.854 & 0.999 \\
\hline $\mathrm{T} 5-B t+$ Urea & 75.694 & 1.535 & 13.603 & 421.191 & $Y=0.490 x+4.052$ & 0.847 & 0.998 \\
\hline $\mathrm{T} 6-B t+\mathrm{EDTA}$ & 85.932 & 1.353 & 15.366 & 480.572 & $Y=0.489 x+4.054$ & 0.809 & 0.997 \\
\hline T4 - Bt + Peptone & 93.464 & 1.244 & 10.910 & 800.697 & $Y=0.384 x+4.244$ & 0.936 & 0.996 \\
\hline
\end{tabular}

Note *Dosage - mortality response was workout for treatments having mortalities $>50 \%$; ${ }^{*}$ Fold increase is $\mathrm{LC}_{50}$ value of $B$. thuringiensis alone divided by the $\mathrm{LC}_{50}$ value of each $B$. thuringiensis + additive mixture. $\pm 95 \%$ fiducially limit (FL)

nous compounds such as peptone, sodium nitrate, and ammonium nitrate enhanced the activity of $B$. thuringiensis $1.62,1.32$ and 1.37 fold, respectively. Wigglesworth (1977) linked the synergistic effects of nitrogenous substances and $B$. thuringiensis in the regulation of lepidopteran larvae to changes in the physiology of haemolymph generated by leakage through the $B$. thuringiensis treated larval midgut cells.

\section{Effects of $B$. thuringiensis and protein solubilizing agents}

With an $L C_{50}$ value of $75.694 \mathrm{mg} / \mathrm{l}$, the synergistic effect of the $B$. thuringiensis plus urea mixture enhanced the mortality of second instar larvae of FAW from 48.86 per cent (Bt alone) to 71.12 per cent on 168 HAT with 57.68 per cent survivors showed 51.4 per cent larval weight reduction in comparison over control. The $B t$ plus EDTA mixture increased the mortality from 43.29 per cent (B. thuringiensis alone) to 68.89 per cent on 168 HAT with an $\mathrm{LC}_{50}$ value of $85.932 \mathrm{mg} / \mathrm{l}$ (Table 4). The two protein solubilizing agents such as urea and
EDTA improved the efficacy when combined with $B$. thuringiensis. This result was correlated with the findings of Zhang et al.(2013), who reported when B. thuringiensis was combined with EDTA (0.2 per cent) and EDTA- $\mathrm{Na}_{2}$ (0.1 per cent) enhanced the efficiency by 1.62- and 2.31-fold increase in $B$. thuringiensis activity against the Plutella xylostellarespectively. The urea denatured the proteins that reduce the disulphide bonds of protein molecules to sulfhydryl groups, thus increasing the dissolution of the endotoxin in the insect gut, which results in more than $50 \%$ mortality of the second instar of FAW larvae (Nickerson, 1980). In contrast, Salama et al.(1985) observed antagonistic effects of EDTA when coupled with $B$. thuringiensis against the cotton leafworm $S$. littoralis.

\section{Effects of $B$. thuringiensis and organic acids}

The efficiency of $B$. thuringiensis plus citric acid mixtures was much lower $(35.56 \pm 0.33 \%)$ on 168 HAT than $B$. thuringiensis alone. More than 60 per cent of survivors showed 48.19 per cent larval weight reduction in 
comparison over control. The mortality produced with the organic salt (citric acid) alone $(11.11 \%$ ) was also much lower than the cumulative effects with $B$. thuringiensis alone (Table 1). Citric acid failed in improving the efficacy of $B$. thuringiensis when used in a combinationat a concentration of 0.05 percent. Similar results were obtained by Salama et al. (1989) against $A$. ipsiIon. Morris et al.(1995) also found that there was no effect of adding any of four organic acids, namely calcium acetate, lauric acid, sodium thioglycolate and malic acid, to $B$. thuringiensis against the fourth instar $M$. configurata larvae. In contrast, the activity of $B$. thuringiensis against the diamondback moth, $P$. xylostella, was found to be enhanced by malic acid and citric acid (Zhang et al., 2013).

\section{Conclusion}

According to the present study, sodium nitrate promoted maximum synergistic interaction with $B$. thuringiensis sub sp kurstaki product Dipel ${ }^{\circledR}$ followed by boric acid, urea, EDTA and peptone against second instar FAW larvae and so significantly $(5 \%)$ contributed to pest control. However, more field tests with these effective chemical adjuvants in combination with the $B$. thuringiensis product are required for further validation.

\section{ACKNOWLEDGEMENTS}

I convey my grateful acknowledgement and thanks to our Dean, Professor and Head of Entomology, Chairman and Members for their active guidance and constant support throughout the completion of this study.

\section{Conflict of interest}

The authors declare that they have no conflict of interest.

\section{REFERENCES}

1. Ashok, K., Kennedy, J.S., Geethalakshmi, V., Jeyakumar, P., Sathiah, N. \& Balasubramani, V. (2020). Lifetable study of fall armyworm Spodoptera frugiperda (JE Smith) on maize. Indian Journal of Entomology, 82(3), pp.574579.doi.org/10.5958/0974-8172.2020.00143.1

2. Baum JA, Johnson TB, Carlton BC. (1999). Bacillus thuringiensis : Natural and recombinant bioinsecticide products. In: Menn JJ, Hall FR (eds) Biopesticides: use and delivery. Humana Press, Totowa, NJ, pp 189-210. 10.1385/0-89603-515-8:189

3. Finney, D.J. (1971). Probit analysis 3rd edition. Cambridge University, London, UK, 333.

4. Goergen, G., Kumar, P.L., Sankung, S.B., Togola. A., Tamo, M. (2016). First report of outbreaks of the Fall Armyworm Spodoptera frugiperda (J E Smith) (Lepidoptera, Noctuidae), a New Alien Invasive Pest in West and Central Africa. PLoS ONE 11(10): e0165632. doi.org/10.1371/journal.pone.0165632
5. Govindarajan, R., Jayaraj, S. \& Narayanan, K. (1976). Mortality of the tobacco caterpillar, Spodoptera litura (F.), when treated with Bacillus thuringiensis combinations with boric acid and insecticides. Phytoparasitica, 4(3), pp.193 -196.doi.org/10.1007/BF02981086

6. Luginbill, P. (1928). The fall armyworm. United States departament of agriculture, Washington, DC, USA. Te chnical Bulletin, 34

7. Malaikozhundan, B., Vaseeharan, B., Vijayakumar, S. \& Thangaraj, M.P. (2017). Bacillus thuringiensis coated zinc oxide nanoparticle and its biopesticidal effects on the pulse beetle, Callosobruchus maculatus. Journal of Photochemistry and Photobiology B: Biology, 174, pp.306314.doi.org/10.1016/j.jphotobiol.2017.08.014

8. Marzban, R., He, Q., Liu, X. \& Zhang, Q. (2009). Effects of Bacillus thuringiensis toxin Cry1 Ac and cytoplasmic polyhedrosis virus of Helicoverpa armigera (Hübner)(HaCPV) on cotton bollworm (Lepidoptera: Noctuidae). Journal of Invertebrate Pathology, 101(1), pp.71-76.doi.org/10.1016/ j.jip.2009.02.008

9. Montezano, D.G., Sosa-Gómez, D.R., Specht, A., RoqueSpecht, V.F., Sousa-Silva, J.C., Paula-Moraes, S.D., Peterson, J.A. \& Hunt, T.E. (2018). Host plants of Spodoptera frugiperda (Lepidoptera: Noctuidae) in the Americas. African Entomology, 26(2), pp.286-300.doi.o $\mathrm{rg} / 10.4001 / 003.026 .0286$

10. Morris, O. N., Converse, V., \& Kanagaratnam, P. (1995). Chemical additive effects on the efficacy of Bacillus thuringiensis Berliner subsp. kurstaki against Mamestra configurata (Lepidotera:Noctuidae). Journal of Economic Entomology, 88, 815-824.doi.org/10.1093/jee/88.4.815

11. Nagoshi, R.N., Goergen, G., Tounou, K.A., Agboka, K., Koffi, D. \& Meagher, R.L. (2018). Analysis of strain distribution, migratory potential, and invasion history of fall armyworm populations in northern Sub-Saharan Africa. Scientific Reports, 8(1), pp.1-10.doi.org/10.1038/s41 598-018-21954-1

12. Nickerson, K. W. (1980). Structure and function of the Bacillus thuringiensis protein crystal. Biotechnology and Bioengineering, 22(7), 1305-1333. doi.org/10.1002/bit.2 60220704

13. Nickerson, K.W. (1980). Structure and function of the Bacillusthuringiensis protein crystal. Biotechnology and Bioengineering, 22(7), pp.1305-1333.doi.org/10.1002/bit.26 0220704

14. Opisa, S., Akutse, K.S., du Plessis, H., Fiaboe, K.K.M. \& Ekesi, S. (2020). Chemical additives enhance the activity of a $B t \square$ based biopesticide targeting the beet webworm larvae. Journal of Applied Entomology, 144(1-2), pp.2632. doi.org/10.1111/jen.12706

15. Salama, H.S., Foda, M.S. \& Sharaby, A. (1985). Potential of some chemicals to increase the effectiveness of Bacillus thuringiensis Berliner against Spodoptera littoralis (Boisd.). Zeitschrift für Angewandte Entomologie, 100(15), pp.425-433.doi.org/10.1111/j.1439-0418.1985.tb0280 1.x

16. Salama, H.S., Foda, M.S. \& Sharaby, A. (1989). Potentiation of Bacillusthuringiensis endotoxin against the greasy cutworm Agrotis ipsilon. Journal of Applied Entomology, 108(1-5),pp.372380.doi.org/10.1111/j.1439 0418.198 9.tb $00470 . x$ 
17. Songa, J.M., Bergvinson, D. \& Mugo, S. (2004). Mass rearing of the maize stem borers Chilo partellus, Busseola fusca, Sesamia calamistis, Chilo orichalcociliellus and Eldana saccharina at KARI, Katumani. Integrated Approaches to Higher Maize Productivity in the New Millennium: Proceedings of the Seventh Eastern and Southern Africa Regional Maize Conference, 5-11 February, 2002 (pp. 120-124).
18. Wigglesworth, V.(1977). The Principles of Insect Physiology. 7th ed. London, UK: English Language Book Society: Chapman and Hall.

19. Zhang, L.,Qiu, S., Huang, T., Huang, Z., Xu, L., Wu, C., Gelbič, I. \& Guan, X. (2013). Effect of chemical additives on Bacillus thuringiensis (Bacillales: Bacillaceae) against Plutella xylostella (Lepidoptera: Pyralidae). Journal of Economic Entomology, 106(3), pp.1075-1080.doi.or $\mathrm{g} / 10.1603 / \mathrm{EC} 12288$ 